\title{
Importance of residual trees to birds in regenerating pine plantations
}

\author{
Brice B Hanberry ${ }^{(1)}$, Phillip Hanberry ${ }^{(1)}$, Stephen Demarais ${ }^{(2)}$, Jeanne C \\ Jones $^{(2)}$
}

Pine plantation establishment methods can alter vegetation composition and structure, thus affecting habitat important characteristics for declining early successional bird species. We evaluated eight vegetation characteristics, which varied due to a range of pine plantation establishment methods, to identify vegetation most closely associated with spring bird abundance in the Lower Coastal Plain of southern Mississippi, USA. Presence of residual trees and snags was positively related to relative abundance of 10 of 14 common species present in regenerating stands. Cover of woody vegetation was positively related to relative abundance of 4 species and negatively related to relative abundance of 2 species. For 5 species, increasing pine tree cover had a negative relationship with relative abundance. Residual trees and snags contributed to avian abundance and richness in regenerating pine plantations. Integration of habitat elements, such as residual trees that influence abundance of birds and other wildlife, with intensive pine plantation establishment can aid managers to attain wildlife conservation in intensively managed stands.

Keywords: Forest Management, Establishment, Habitat, Site Preparation, Snags

\section{Introduction}

The southeastern United States is the largest national source of timber, supported by growth of intensively managed pine plantations (Haynes 2002). Common stand establishment procedures to control hardwood and herbaceous plant growth in pine plantations incorporate chemical or mechanical methods during site preparation before planting and chemical herbaceous controls after planting. Chemical herbaceous controls can be applied in a band along a row of crop trees or broadcast throughout a stand. Suppression of herbaceous vegetation and nonmerchantable hardwoods through herbicides

(1) School of Natural Resources, 203 Natural Resources Building, University of Missouri, Columbia, MO 65211 USA; (2) Department of Wildlife and Fisheries, Box 9690, Mississippi State University, Mississippi State, MS 39762, USA

@) Brice Hanberry

(hanberryb@missouri.edu)

Received: Feb 01, 2012 - Accepted: May 05, 2012

Citation: Hanberry BB, Hanberry $P$, Demarais S, Jones JC, 2012. Importance of residual trees to birds in regenerating pine plantations. iForest 5: 108-112 [online 201206-05] URL:

http://www.sisef.it/iforest/contents? id=ifor $0616-005$ and mechanical methods may affect wildlife by altering critical early successional habitat (Lautenschlager 1993). Intensity of vegetation disturbance, timing (at site preparation or as a later control after planting), and treatment type (herbicide versus mechanical or both) may affect wildlife differentially.

Vegetation provides nesting sites, foraging opportunities, cover from predators, and perches for song and display for birds (Martin 1988, Steele 1993, Holmes \& Schultz 1988). Insects, the primary food source for birds during breeding season, may fluctuate in abundance and composition in response to vegetative changes (Santillo et al. 1989). Vegetative structure and composition affect nest predation and food limitation, which ultimately may impact reproduction (Martin 1995, Nagy \& Holmes 2004). There has been some question about greater influence of vegetative structure or composition, but composition may vary geographically and therefore, be nested hierarchically within structure, with species-specific balances between both features (Robinson \& Holmes 1984, Orians \& Wittenberger 1991).

Diversity and provision for wildlife communities are important for many stakeholders, including the forest products industry, which has sustainable forestry certification systems in place (Jones et al. 2010a). Intensive pine plantation establishment may affect vegetation characteristics important to bird species, particularly early successional bird species that, in general, are declining across the eastern United States (Panjabi et al.
2005). The purpose of this study was to assess spring bird response to changes in vegetation generated by a stand establishment intensity continuum, which increased in intensity due to combinations of mechanical and chemical site preparation and chemical control after planting. We modeled relationships between avian species of concern to eight vegetation variables affected by different establishment practices in the lower Coastal Plain of southern Mississippi. Results from this study provide important information for integrating plantation and wildlife management.

\section{Methods}

Study area and plantation establishment The four study sites, which averaged 66 ha (50 to 75 ha), were loblolly pine (Pinus taeda L.) plantations in the lower Coastal Plain, Mississippi, USA. The study sites were within $75 \mathrm{~km}$ of each other and similar in climate, vegetation, and management (Jones et al. 2009). Soil and topography varied: two sites were flat with somewhat poorly drained alfisols, one site was flat with well-drained ultisols, and one site was gently sloping from 95 to $121 \mathrm{~m}$ with well-drained primarily alfisols (Soil Survey Geographic SSURGO Database, USDA Natural Resources Conservation Service, http://soildatamart.nrcs.usda.gov).

Apart from establishment practices of site preparation and herbaceous control after planting, management was standardized across all sites. All study sites were previously loblolly or slash ( $P$. elliottii Engelm.) pine plantations, harvested during summer 2000-winter 2001 and planted with loblolly pine during winter 2001-2002. Each forest product industry cooperator provided proprietary genetically-improved seedlings. Tree spacing was $3.0 \mathrm{~m}$ between rows and $2.1 \mathrm{~m}$ between trees within a row, totaling 1551 trees ha $^{-1}$. Two sites were machine planted and two sites were planted by hand, due to greater post-harvest debris loads. Banded herbaceous control treatments were applied with a band width of $1.5 \mathrm{~m}$ to every tree row or broadcast herbicide applications were applied by helicopter. All treatments received a broadcast application of diammonium phosphate at $280 \mathrm{~kg} \mathrm{ha}^{-1}$ during spring 2002.

Each site contained 5 treatment levels, representing a range of operational stand establishment intensities. Each treatment was assigned randomly to a minimum of 8 ha per stand, in a randomized complete block design. Management intensity, and thus expected vegetative impact, increased from low for one type of site preparation only and a banded herbaceous control, CHEM and $\mathrm{MECH}$, to high for two years of broadcast 
Tab. 1 - Five stand establishment treatments varying from low (CHEM and MECH) to high (BROAD2) intensity in the Lower Coastal Plain of Mississippi, USA. Site preparation occurred before planting (2001 to 2002) and chemical herbaceous control occurred after planting. The banded chemical control covered the tree row and the broadcast chemical control was applied to the entire plot.

\begin{tabular}{lccccc}
\hline \multirow{2}{*}{$\begin{array}{c}\text { Establishment } \\
\text { type }\end{array}$} & CHEM & MECH & COMBO & BROAD & BROAD2 \\
\cline { 2 - 6 } $\begin{array}{l}\text { Site } \\
\text { preparation }\end{array}$ & Chemical & Mechanical & $\begin{array}{c}\text { Mechanical } \\
\text { and Chemical }\end{array}$ & $\begin{array}{c}\text { Mechanical } \\
\text { and Chemical }\end{array}$ & $\begin{array}{c}\text { Mechanical } \\
\text { and Chemical }\end{array}$ \\
$\begin{array}{l}\text { Chemical } \\
\text { control }\end{array}$ & Banded & Banded & Banded & Broadcast & Broadcast \\
\hline
\end{tabular}

herbaceous control following site preparation, BROAD2 (Tab. 1).

- Chemical site preparation only, CHEM, consisted of a broadcast solution of $2.4 \mathrm{~L}$ ha $^{-1}$ Chopper ${ }^{\circledR}$ (BASF Corp., Research Triangle Park, North Carolina; imazapyr; 32 oz. acre $^{-1}$ ), $3.5 \mathrm{~L} \mathrm{ha}^{-1}$ Accord ${ }^{\circledR}$ (Dow AgroSciences LLC, Indianapolis, Indiana; glyphosate; $48 \mathrm{oz}$. acre $\left.^{-1}\right), 3.5 \mathrm{~L} \mathrm{ha}^{-1}$ Garlon 4 (Dow AgroSciences LLC, Indianapolis, Indiana; triclopyr; $48 \mathrm{oz}$. acre $\left.^{-1}\right)$, and $1 \%$ Timberland 90® surfactant (UAP Timberland LLC, Monticello, Arkansas) during summer 2001 followed by a banded (along tree rows) chemical control with $0.9 \mathrm{~kg}$ ha $^{-1}$ of Oustar ${ }^{\circledR}$ (E. I. du Pont de Nemours and Company, Inc., Wilmington, Delaware; hexazinone and sulfometuron; $13 \mathrm{oz}$. acre $^{-1}$ ) during spring 2002.

- Mechanical site preparation only, MECH, incorporated a combination plow to rip, disk, and bed the soil, and a V-blade to clear debris during fall 2001, and the same banded chemical control as CHEM.

- Site preparation for COMBO combined the mechanical and chemical site preparation of CHEM and MECH, along with the banded control.

- BROAD combined the same mechanical and chemical site preparation along with a single year of broadcast (over entire area) chemical control using $0.9 \mathrm{~kg} \mathrm{ha}^{-1}$ of Oustar ${ }^{\circledR}$ during spring 2002.

- BROAD2 was identical to BROAD except for an additional broadcast chemical control during spring 2003.

\section{Sampling}

We surveyed breeding birds during midApril through mid-June 2002-2006 with 10minute point counts (Verner 1985). In each treatment, we established 3 point count stations ranging from $150-230 \mathrm{~m}$ apart and at least $50 \mathrm{~m}$ distant from treatment boundaries. Using a laser range finder to increase distance estimation accuracy, we recorded birds that were within $75 \mathrm{~m}$ of each station although we subsequently removed any observations $>50 \mathrm{~m}$. We completed 3 survey repetitions during 2002 and 6 repetitions during 2003-2006 that occurred between sunrise and 11:00 am during optimal weather conditions: no rain or low cloud cover, minimal wind and fog.

Vegetation was sampled during 2002 to 2006 in a companion study (Jones et al. 2009, Jones et al. 2010a - Appendix 1). Within each treatment, $103-\mathrm{m}$ transects were established to assess vegetation characteristics. Percent coverage of understory herbaceous species, woody species, and debris were recorded using a modification of Canfield's (Canfield 1941) line-intercept method. Plants were identified to species and then grouped by growth form type (i.e., grass and grass-like, forbs excluding legumes, legumes, pine trees, woody non-pine shrubs and trees, vines). Independent of the vegetation study, we counted residual trees and snags $>2 \mathrm{~m}$ in height or $>10 \mathrm{~cm}$ in diameter within $10 \mathrm{~m}$ along one side of an established belt transect for winter bird surveys.

A companion vegetation study showed the establishment intensity gradient created vegetation differences among treatments (Jones et al. 2009, Jones et al. 2010 - Appendix 1). During 2002-2006, total vegetation cover generally was greatest in $\mathrm{MECH}$, least in BROAD2, and intermediate in COMBO, BROAD, and CHEM. During 2004-2006, height growth of pine trees averaged $1.36 \mathrm{~m}$ $\mathrm{yr}^{-1}$ across all treatments. Increasing establishment intensity increased pine tree height, diameter, and coverage. CHEM had the lowest growth rate, while BROAD2 had the greatest, and the other treatments were intermediate. BROAD2 averaged $1.4 \mathrm{~m}$ taller and $2.4 \mathrm{~cm}$ greater in diameter than CHEM. Correspondingly, pine coverage was greatest in BROAD and BROAD2 and least in MECH and CHEM. Coverage of understory herbaceous plants in all treatments declined from $85-125 \%$ during 2004 to 44 $76 \%$ during 2006. Coverage of understory herbaceous plants decreased with increasing intensity; BROAD2 averaged $65 \%$ of MECH. Woody plant coverage, excluding pines, had a marginal treatment effect $\left(F_{4,42}=\right.$ 2006. $2.56, P=0.053)$ and increased from 2004 to

\section{Modeling}

We selected 14 bird species for modeling that indicated some difference among treatments (i.e., probable response to vegetation; $P$ value $<0.2$ - Hanberry 2007), were regionally less common (Panjabi et al. 2005), and were not rare observations in the study sites (selected species had 39 to 707 observations). We also included brown-headed cowbird (Molothrus ater), a nest parasite, which was not a declining species. Vegetation variables consisted of coverage of bare ground and debris (BGandD), grass and grass-like (GandGL), forbs excluding legumes, legumes, pine trees, woody non-pine shrubs and trees, vines, and number of residual trees and snags (Snag).

We used a repeated measures, mixed model analysis of variance to model bird counts and vegetation using all possible combinations of vegetation through 5 predictor variables (PROC MIXED - SAS software, version 9.1, Cary, North Carolina, USA). Site was a random effect (because each site contained the five treatments) and year was a repeated measure. To account for time, year was a variable in all models. Using least $\mathrm{AIC}_{\mathrm{c}}$ (Akaike's Information Criterion corrected for small sample size) value, we selected the covariance structure with the best fit from autoregressive, compound symmetry, autoregressive heterogeneous, and compound symmetry heterogeneous options (Gutzwiller \& Riffell 2007). We square-root transformed counts if data transformation reduced $\mathrm{AIC}_{\mathrm{c}}$ values. The models were ranked by $\mathrm{AIC}_{\mathrm{c}}$ from least to greatest value, followed by calculation of differences among models $\left(\triangle \mathrm{AIC}_{\mathrm{c}}\right)$ and their Akaike weights. For models within $2 \mathrm{AIC}_{\mathrm{c}}$ units of the top model, we calculated a Pearson correlation coefficient (PROC CORR) by comparing observed bird abundance to predicted bird abundance based on the model for every sample point. Because many of the bird species had models of approximately equal weight and correlation, we removed models with more variables when there was a reduced model with fewer predictor variables.

\section{Results}

Bird species that had models with relatively high prediction rates $(r>0.70)$ along with greater abundance were yellow-breasted chat (Icteria virens: count $=707$ observations), common yellowthroat (Geothlypis trichas: 373 observations), prairie warbler (Setophaga discolor: 389 observations), white-eyed vireo (Vireo griseus: 165 observations), indigo bunting (Passerina cyanea: 569 observations), and eastern towhee ( $P i$ pilo erythrophthalmus: 308 observations; Tab. 2). Field sparrow (Spizella pusilla: 57 observations), brown-headed cowbird (43 observations), brown thrasher (Toxostoma rufum: 39 observations), eastern kingbird 
Tab. 2 - Avian models from 5 pine plantation establishment practices varying from low to high intensity during years 1-5 post-treatment (April - June 2002 - 2006) in the Mississippi Lower Coastal Plain. (a): year is a variable in all models and produces 5 additional parameters; (b): snag is residual trees, BGandD is bare ground and debris, GandGL is grass and grass-like; (c): $\mathrm{K}$ is number of parameters; (d): $r$ is correlation between observed bird abundance and predicted bird abundance.

\begin{tabular}{|c|c|c|c|c|c|c|}
\hline Species & Model $^{(\mathbf{a b})}$ & $K^{(c)}$ & $\mathbf{A I C} \mathbf{C}^{(\mathbf{c})}$ & $\Delta \mathrm{AIC}^{(\mathrm{c})}$ & Weight & $r^{(d)}$ \\
\hline Brown-headed cowbird & $\begin{array}{l}(+) \text { Woody } \\
(+) \text { Snag }\end{array}$ & 9 & -224.2 & 0.80 & 0.12 & 0.58 \\
\hline Blue grosbeak & (-) Woody & 8 & -85.2 & 0.50 & 0.15 & 0.47 \\
\hline Brown thrasher & $\begin{array}{l}\text { (+) Woody } \\
(+) \text { Snag }\end{array}$ & 9 & -222.0 & 1.60 & 0.31 & 0.60 \\
\hline Carolina chickadee & (+) Snag & 8 & -175.2 & 0.00 & 0.09 & 0.39 \\
\hline Carolina wren & $(+)$ Snag & 8 & -171.2 & 0.00 & 0.28 & 0.59 \\
\hline Common yellowthroat & (-) Pine & 8 & 17.9 & 1.00 & 0.07 & 0.80 \\
\hline Eastern kingbird & (+) Snag & 8 & -121.4 & 0.00 & 0.54 & 0.60 \\
\hline Eastern towhee & $\begin{array}{l}\text { (-) Forb } \\
\text { (+) Woody } \\
\text { (+) Snag }\end{array}$ & 10 & -24.2 & 0.00 & 0.54 & 0.71 \\
\hline Field sparrow & $\begin{array}{l}\text { (+) GandGL } \\
\text { (+) Snag }\end{array}$ & 9 & -159.0 & 1.50 & 0.17 & 0.69 \\
\hline Indigo bunting & $\begin{array}{l}\text { (-) BGandD } \\
\text { (-) Woody } \\
\text { (+) Snag }\end{array}$ & 10 & 43.6 & 1.40 & 0.21 & 0.77 \\
\hline Orchard oriole & $\begin{array}{l}\text { (+) BGandD } \\
\text { (+) Forb } \\
\text { (-) Pine }\end{array}$ & 10 & -71.5 & 0.30 & 0.33 & 0.45 \\
\hline Prairie warbler & $\begin{array}{l}\text { (-) Pine } \\
\text { (+) Snag }\end{array}$ & 9 & -31.0 & 0.00 & 0.40 & 0.81 \\
\hline White-eyed vireo & $\begin{array}{l}\text { (-) Pine } \\
(+) \text { Woody }\end{array}$ & 9 & -103.7 & 0.00 & 0.19 & 0.78 \\
\hline Yellow-breasted chat & $\begin{array}{l}\text { (+) BGandD } \\
\text { (-) Pine } \\
\text { (+) Vine } \\
\text { (+) Snag }\end{array}$ & 11 & 0.3 & 1.90 & 0.22 & 0.80 \\
\hline
\end{tabular}

(Tyrannus tyrannus: 39 observations), and Carolina wren (Thryothorus ludovicianus: 50 observations) had less powerful models with $r$ values of $0.59-0.69$. Vegetation explained less variation (models with $r$ values of $<0.50)$, despite relatively moderate abundance, for Carolina chickadee (Poecile carolinensis: 48 observations), blue grosbeak (Passerina caerulea: 94 observations), and orchard oriole (Icterus spurius: $110 \mathrm{ob}-$ servations).

The most frequently represented variable was residual trees, which were in models for 10 of 14 species and positively associated with relative abundance. Percent cover of woody vegetation was positively related to relative abundance of brown-headed cowbirds, brown thrasher, eastern towhee, and white-eyed vireo, but negatively related to detections of blue grosbeak and indigo bunting. Increasing pine tree cover had a negative relationship with relative abundance of common yellowthroat, orchard oriole, prairie warbler, white-eyed vireo, and yellowbreasted chat. Bare ground and debris, and the herbaceous variables of grasses and when snags and nest sites were available (Dickson et al. 1983, Caine \& Marion 1991). Lohr et al. (2002) reported that snag removal reduced abundance of Carolina wren but not Carolina chickadee in loblolly forests of South Carolina.

Although there is an obvious relationship between cavity nesters to snags, few studies emphasize importance of retained trees for other breeding birds. Many bird species also use trees for nest sites, perches, singing or display posts, sighting prey, and foraging. Additionally, snag removal may reduce substrate for some insects, possibly reducing prey sources for insectivorous birds. Snags in regenerating pine plantations may increase total abundance and species richness of avian species (Johnson \& Landers 1982, Dickson et al. 1983, Caine \& Marion 1991). Dickson et al. (1983) noted increased presence of yellow-breasted chats and brownheaded cowbirds in plots with snags versus snag-less plots in an east Texas, USA clearcut. In contrast to our models, Dickson et al. (1983) found that blue grosbeak, field sparrows, and prairie warblers were more abundant on plots devoid of standing snags, whereas indigo buntings and common yellowthroats did not differ in abundance between snag and snag-less plots.

Woody shrubs and pine and non-pine trees were influential model variables and their proportions were altered by establishment treatments. Young woody vegetation provides habitat for early successional bird species in regenerating stands and thus produced a mix of generally positive but some negative relationships. For example, woody vegetation was important for brown thrasher, eastern towhee, and white-eyed vireo, which prefer thickets (Hopp et al. 1995, Greenlaw 1996, Cavitt \& Haas 2000). Additionally, woody vegetation was more influential than grasses on abundance of other bird species and therefore, brown-headed cowbirds were associated with woody vegetation where their hosts were present. In contrast to other variables, pine trees were negative model variables. Growing pine trees replaced other vegetation over time, thus negative associations for five species may result from vegetation displacement rather than pine tree cover. Herbaceous variables of grasses, legumes, forbs, and vines were uncommon or absent in models and appeared to be less influential than residual trees, woody vegetation, and pine trees for the suite of species that were common in regenerating stands.

Although density is generally a good predictor of reproductive success (Bock \& Jones 2004), higher quality habitat does not always equal greater density, and likewise, greater density does not necessarily equal higher quality habitat. Density and habitat quality can be decoupled by at least (1) territoriality and other social interactions, (2) 
source-sink dynamics, (3) ecological traps, (4) migrant deception, or site tenacity after habitat change, (5) patchy resources, and (6) predation. In species with strong social interactions, particularly generalists with high reproduction rates, dominant individuals can force subdominants into marginal habitat to the extent that density is greater in lower quality habitats (Van Horne 1983). Density also can be inflated artificially in low quality population sinks that are supported by regional population sources (Pulliam 1988). Animals correctly evaluate habitat quality, yet source habitat is limited. Anthropogenic disturbance can disconnect habitat preference and reproduction (Bock \& Jones 2004) in the overlapping cases of ecological traps and migrant deception. Density can be high yet reproductive success low in sink habitat that is preferred (Dwernychuk \& Boag 1972, Battin 2004). For example, ecological traps can occur in locations with elevated numbers of nest predators or brood parasites, specifically in areas that historically contained reduced levels (Robertson \& Hutto 2006), or grassland species can lose nests to early mowing. Disturbance-dependent species particularly may be vulnerable to ecological traps, mistaking artificial disturbance for natural disturbance (Weldon \& Haddad 2005) Overstocking also may develop when birds settle in a previously successful breeding site, without recognizing recent habita modification, whether from natural disturbance or land use and management (Wiens et al. 1986, Lautenschlager 1993). Density undersaturation can occur in high quality habitat when resources fluctuate spatially or temporally, due to factors such as weather, disturbance, or vegetation ecology (Wiens 1981, Van Horne 1983).

In this study, we modeled effects from chemical and mechanical alteration of vegetation and avian abundance. Many of the problems associated with count data were reduced by a randomized block design, where all sites contain every treatment. Adjacent treatments therefore were affected equally by outside and historical events, negating regional source/sink influences and reducing differential migrant deception, patchiness, and exposure to ecological traps. We also estimated associations within similar plant communities, which again minimized differences. In addition, modeling of species during breeding season avoided a heavy influx of juveniles and wandering flocks.

\section{Conclusions}

Residual trees appeared to be a critical stand element for many bird species in the study sites and retaining trees may help realize integration of fiber production and management of wildlife diversity. Tree retention enriched avian assemblages in young, intensively established pine plantations in this study and results should translate to other intensively managed stands across the southeastern United States and where residual tree density is low. Furthermore, a variety of small mammals, including bats, reptiles, and amphibians use mature trees and snags for foraging, nesting, roosting, and denning. Therefore, retaining trees at harvest and stand establishment is the primary management recommendation, particularly if the biomass industry increases removal of woody material, leaving stands cleaned of small diameter stems, snags, and cull trees. Tree retention requires knowledge of number, species, size, and spatial distribution of trees to most efficiently benefit birds and other wildlife. This information currently is undeveloped, particularly in the southeastern United States, and will require experimental manipulation along with model development.

\section{Acknowledgements}

This study was funded by the National Council for Air and Stream Improvement, Inc., Weyerhaeuser Company, International Paper Company, MeadWestvaco, Boise Cascade Corporation, Federal Aid in Wildlife Restoration (Project W-48, Study 57), and the Mississippi Department of Wildlife, Fisheries and Parks. Plum Creek Timber Company, Molpus Timberlands, and Weyerhaeuser Company provided study sites and treatment installation. Mississippi State University Department of Wildlife and Fisheries supplied facilities. T. B. Wigley, D. A. Miller, and reviewers provided appreciated suggestions.

\section{References}

Battin J (2004). When good animals love bad habitats: ecological traps and the conservation of animal populations. Conservation Biology 18: 1482-1491. - doi: 10.1111/j.1523-1739.2004. 00417.x

Bock CE, Jones ZF (2004). Avian habitat evaluation: should counting birds count? Frontiers in Ecology and Environment 2: 403-410. - doi: 10.1890/1540-9295(2004)002[0403:AHESCB]

\subsection{CO;2}

Caine LA, Marion WR (1991). Artificial addition of snags and nest boxes to slash pine plantations. Journal of Field Ornithology 62: 97-106. [online] URL: http://www.jstor.org/stable/4513610

Canfield RH (1941). Application of the line interception method in sampling range vegetation. Journal of Forestry 39 (4): 388-394.

Cavitt JF, Haas CA (2000). Brown Thrasher (Toxostoma rufum). In: "The birds of North America: No. 557" (Poole A, Gill F eds). The American Ornithologists' Union, Washington, DC, USA. Conner RN (1978). Snag management for cavity nesting birds. In: Proceedings of the workshop on "Management of Southern Forests for Nongame Birds" (DeGraaf RM ed). Gen. Tech. Rep. SE-14, USDA Forest Service, Asheville,
NC, USA, pp. 120-128.

Davis JW (1983). Snags are for wildlife. Proceedings of the "Symposium on Snag Habitat Management" (Davis JW, Goodwin GA, Okenfels RA technical coordinators). Gen. Tech. Rep. RM-99, Fort Collins, CO, USDA Forest Service, pp. 4-8.

Dickson JG, Conner RN, Williamson JH (1983). Snag retention increases bird use of a clear-cut. Journal of Wildlife Management 47: 799-804. doi: $10.2307 / 3808615$

Dwernychuk LW, Boag DA (1972). Ducks nesting in association with gulls - an ecological trap? Canadian Journal of Zoology 50: 559-563. - doi: 10.1139/z72-076

Fox TR, Jokela EJ, Allen HL (2007). The development of pine plantation silviculture in the southern United States. Journal of Forestry 105 (7): 337-47.

Greenlaw JS (1996). Eastern Towhee (Pipilo erythrophthalmus). In: "The birds of North America: No. 262" (Poole A, Gill F eds). The American Ornithologists' Union, Washington, DC, USA.

Gutzwiller KJ, Riffell SK (2007). Using statistical models to study temporal dynamics of animal-landscape relations. In: "Temporal dimensions of landscape ecology: wildlife responses to variable resources" (Bissonette JA, Storc I eds). Springer, New York, USA, pp. 93-118.

Hanberry BB (2007). Birds and small mammals, intensively established pine plantations, and landscape metrics of the Coastal Plain. PhD Thesis, Department of Wildlife and Fisheries, Mississippi State University, Baton Rouge, USA, pp. 140.

Haynes RW (2002). Forest management in the $21^{\text {st }}$ century: changing numbers, changing context. Journal of Forestry 100 (2): 38-43. [online] URL: http://www.esf.edu/for/germain/Haynes 2002b.pdf

Holmes RT, Schultz JC (1988). Food availability for forest birds: effects of prey distribution and abundance on bird foraging. Canadian Journal of Zoology 66: 720-728. - doi: 10.1139/z88-107

Hopp SL, Kirby A, Boone CA (1995). White-eyed Vireo (Vireo griseus). In: "The birds of North America: No. 168" (Poole A, Gill F eds). The American Ornithologists' Union, Washington, DC, USA.

Johnson AS, Landers JL (1982). Habitat relationships of summer resident birds in slash pine flatwoods. Journal of Wildlife Management 46: 416428. - doi: 10.2307/3808653

Jones PD, Edwards SL, Demarais S, Ezell AW (2009). Vegetation community responses to different establishment regimes in loblolly pine (Pinus taeda) plantations in southern MS, USA. Forest Ecology and Management 257: 553-560. doi: 10.1016/j.foreco.2008.09.033

Jones PD, Burger LW, Demarais S (2010a). Habitat value of intensively established pine plantations for northern bobwhite. Journal of Wildlife Management 74: 449-458. - doi: 10.2193/2009. 137

Jones PD, Hanberry BB, Demarais S (2010b). 
Managing the southern pine forest-retained wetland interface for wildlife diversity: research priorities. Wetlands 30: 381-391. - doi: 10.1007/ s13157-010-0060-8

Lautenschlager RA (1993). Response of wildlife to forest herbicide applications in northern coniferous ecosystems. Canadian Journal of Forest Research 23: 2286-2299. - doi: 10.1139/x93-283 Lohr SM, Gauthreaux SA, Kilgo JC (2002). Importance of coarse woody debris to avian communities in loblolly pine forests. Conservation Biology 16: 767-777. - doi: 10.1046/j.15231739.2002.01019.x

Martin TE (1988). Habitat and area effects on forest bird assemblages: is nest predation an influence? Ecology 69: 74-84. - doi: 10.2307/ 1943162

Martin TE (1995). Avian life history evolution in relation to nest sites, nest predation, and food. Ecological Monographs 65: 101-127. - doi: $10.2307 / 2937160$

Nagy LR, Holmes RT (2004). Factors influencing fecundity in migratory songbirds: is nest predation the most important? Journal of Avian Biology 35: 487-491. - doi: 10.1111/j.0908-8857. 2004.03429.x

Orians GH, Wittenberger JF (1991). Spatial and temporal scales in habitat selection. American Naturalist 137: S29-S49. - doi: 10.1086/an.1991. 137.issue-s1

Panjabi AO, Dunn EH, Blancher PJ, Hunter WC, Altman B, Bart J, Beardmore CJ, Berlanga H,
Butcher GS, Davis SK, Demarest DW, Dettmers R, Easton W, Gomez de Silva Garza H, IñigoElias EE, Pashley DN, Ralph CJ, Rich TD, Rosenberg KV, Rustay CM, Ruth JM, Wendt JS, Will TC (2005). The partners in flight handbook on species assessment. Version 2005. Partners in Flight Technical Series No. 3, Rocky Mountain Bird Observatory website. [online] URL: http://www.rmbo.org/pubs/downloads/Handbook2005.pdf

Pulliam HR (1988). Sources, sinks, and population regulation. American Naturalist 132: 652661. - doi: 10.1086/284880

Robertson BA, Hutto RL (2006). A framework for understanding ecological traps and an evaluation of existing evidence. Ecology 87: 1075-1085. doi: $\quad 10.1890 / 0012-9658(2006) 87[1075: A F-$ FUET]2.0.CO;2

Robinson SK, Holmes RT (1984). Effects of plant species and foliage structure on the foraging behavior of forest birds. The Auk 101: 672-684. [online] URL: http://www.jstor.org/stable/ 4086894

Santillo DJ, Brown PW, Leslie DM (1989). Response of songbirds to glyphosate-induced habitat changes on clearcuts. Journal of Wildlife Management 53: 64-71. - doi: 10.2307/3801307 Steele BB (1993). Selection of foraging and nesting sites by black-throated Blue warblers: their relative influence on habitat choice. Condor 95: 568-579. - doi: 10.2307/1369601

Van Horne B (1983). Density as a misleading in- dicator of habitat quality. Journal of Wildlife Management 47: 893-901. - doi: 10.2307/ 3808148

Verner J (1985). Assessment of counting techniques. In: "Current Ornithology: Volume 2" (Johnston RF ed). Plenum Press, New York, USA, pp. 247-302.

Weldon AJ, Haddad NM (2005). The effects of patch shape on Indigo Buntings: evidence for an ecological trap. Ecology 86: 1422-1431. - doi: 10.1890/04-0913

Wiens JA (1981). Scale problems in avian censusing. In: "Studies in Avian Biology 6" (Ralph CJ, Scott, JM eds). Cooper Ornithological Society, Lawrence, Kansas, USA, pp. 513-521.

Wiens JA, Rotenberry JT, Van Horne B (1986). A lesson in the limitations of field experiments: shrubsteppe birds and habitat alteration. Ecology 67: 365-376. - doi: 10.2307/1938579

\section{Supplementary Material}

Appendix 1 - Vegetation cover from 5 pine plantation establishment practices varying from low (CHEM and $\mathrm{MECH}$ ) to high (BROAD2) intensity during years 1 to 5 post-establishment (2002 to 2006) in the Lower Coastal Plain of Mississippi, USA.

Link: Hanberry_616@suppl001.pdf 